\title{
New and little-known Cheilostomata (Bryozoa, Gymnolaemata) from the NE Atlantic
}

\author{
Björn BERNING \\ Geoscience Collections, Upper Austrian State Museum, Welser Str. 20, 4060 Leonding, Austria \\ Email: b.berning@landesmuseum.at
}

urn:1sid:zoobank.org:author:7A351E42-FFD7-44A3-B3DE-CF5251B3A3F1

\begin{abstract}
Based on newly designated type material, four poorly known NE Atlantic cheilostome bryozoan species are redescribed and imaged: Cellaria harmelini d'Hondt from the northern Bay of Biscay, Hippomenella mucronelliformis (Waters) from Madeira, Myriapora bugei d'Hondt from the Azores, and Characodoma strangulatum, occurring from Mauritania to southern Portugal. Moreover, Notoplites saojorgensis sp. nov. from the Azores, formerly reported as Notoplites marsupiatus (Jullien), is newly described. The genus Hippomenella Canu \& Bassler is transferred from the lepraliomorph family Escharinidae Tilbrook to the umbonulomorph family Romancheinidae Jullien.
\end{abstract}

Keywords. Bryozoa, Cheilostomata, Macaronesia, new species, taxonomy.

Berning B. 2013. New and little-known Cheilostomata (Bryozoa, Gymnolaemata) from the NE Atlantic. European Journal of Taxonomy 44: 1-25. http:/dx.doi.org/10.5852/ejt.2013.44

\section{Introduction}

Compared with the number of publications on the phylum Bryozoa from the Mediterranean Sea, the subtropical and warm-temperate NE Atlantic faunas have been fairly neglected during the last decades. There are only a handful of recent papers that deal with relatively few species from the NW African and Iberian continental shelf and open ocean islands (e.g., Arístegui 1985; Harmelin \& d'Hondt 1992; López de la Cuadra \& García-Gómez 1993, 1996; López-Fé 2006; Berning 2012). In fact, the most important scientific cruises and collections were made in the late 19th to early 20th century (e.g., Jullien 1883; Jullien \& Calvet 1903; Calvet 1907, 1931), resulting in the introduction of most species prior to the use of scanning electron microscopy (SEM), which is crucial for the detection of subtle yet important morphological differences between bryozoan species. It is, therefore, of vital importance to clearly define the historical species in order to assess the diversity, ecological requirements, and geographic distribution of bryozoan species in the NE Atlantic.

Owing to the research efforts of individual scientists, and particularly during the ongoing project "Fauna Ibérica: Briozoos", with the aim to inventory the entire Iberian bryozoan fauna, a number of NE Atlantic species have already been redescribed or newly introduced very recently (e.g., ReverterGil \& Fernández-Pulpeiro 1999a, b; Reverter-Gil et al. 2009, 2012; Souto et al. 2010, 2011). Other modern studies revising selected genera have revealed that, due to the presence of undifferentiated 
species complexes alone, the bryozoan diversity in the NE Atlantic may be considerably underestimated (Harmelin 1978; Harmelin \& Arístegui 1988; Reverter-Gil \& Fernández-Pulpeiro 1996; Berning \& Kuklinski 2008; Berning et al. 2008).

The present paper deals with another four poorly known and ill-defined species, which are redescribed based on their type specimens: Cellaria harmelini d'Hondt, 1973 from the northern Bay of Biscay, Hippomenella mucronelliformis (Waters, 1899) from Madeira, Myriapora bugei d'Hondt, 1975 from the Azores, and Characodoma strangulatum (Calvet, 1906), apparently occurring from southern Portugal to Mauritania. In addition, a species from the Azores, which has previously been recorded as Notoplites marsupiatus (Jullien, 1883), is newly described.

\section{Material and methods}

The analysed material is preserved in the collections of the Natural History Museum in London (NHMUK), Manchester Museum (MM), the Muséum National d'Histoire Naturelle in Paris (MNHN), the Musée Océanographique de Monaco (MOM), and the Madeiran Museu Municipal (História Natural) in Funchal (MMF). Bryozoan type specimens were digitally photographed at the NHMUK using a LEO 1455VP SEM, and at the MNHN using a Tescan VEGA SEM. Both machines allowed imaging the uncoated specimens with back-scattered electrons in the low vacuum mode. Morphometrics were made on these micrographs using the image software ImageJ. Bryozoan systematics follow the working classification of D.P. Gordon (pers. comm. 2011), who is currently developing the classification scheme for eventual use in the revised Treatise on Invertebrate Paleontology.

\section{Results}

Suborder Neocheilostomina d'Hondt, 1985

Superfamily Buguloidea Gray, 1848

Family Candidae d'Orbigny, 1851

Genus Notoplites Harmer, 1923

Notoplites saojorgensis sp. nov. urn:1sid:zoobank.org:act:19A50609-B149-46AC-9A17-237D31A95867

Fig. 1, Table 1

Notoplites marsupiatus (Jullien, 1883) - Calvet 1931: 69.

Non Scrupocellaria marsupiata - d'Hondt 1975: 556, figs 14-16 (part or whole).

\section{Differential diagnosis}

There are only two other NE Atlantic Notoplites species that have a marginally fimbriated scutum covering the entire opesia: $N$. clausus (Busk, 1884) and $N$. marsupiatus (Jullien, 1883). N. saojorgensis sp. nov. differs from these in generally lacking distal orificial spines, in having wider zooecia and larger scuta, and in having ooecia with a triangular proximomedian fenestra. Moreover, in comparison with $N$. marsupiatus, zooids in the new species are much larger, the ooecia are distinctly shorter, and the orifice is wider than long. Additional differences to $N$. clausus are that the internodes are more robust, that the lateral avicularium is clearly visible in frontal view, and that there are more and longer fissures between marginal branches in the scutum.

\section{Etymology}

The species is named after its type location, São Jorge Island (Azores archipelago). 


\section{Type Material}

\section{Holotype}

MNHN 4163, a large free colony, Princess Alice Stn 1349, 1250 m, 19 Aug. 1902, 38³5’30" N $-28^{\circ} 05^{\prime} 45^{\prime}$ W (Azores, off south-central São Jorge Island), on sandy mud of volcanic origin.
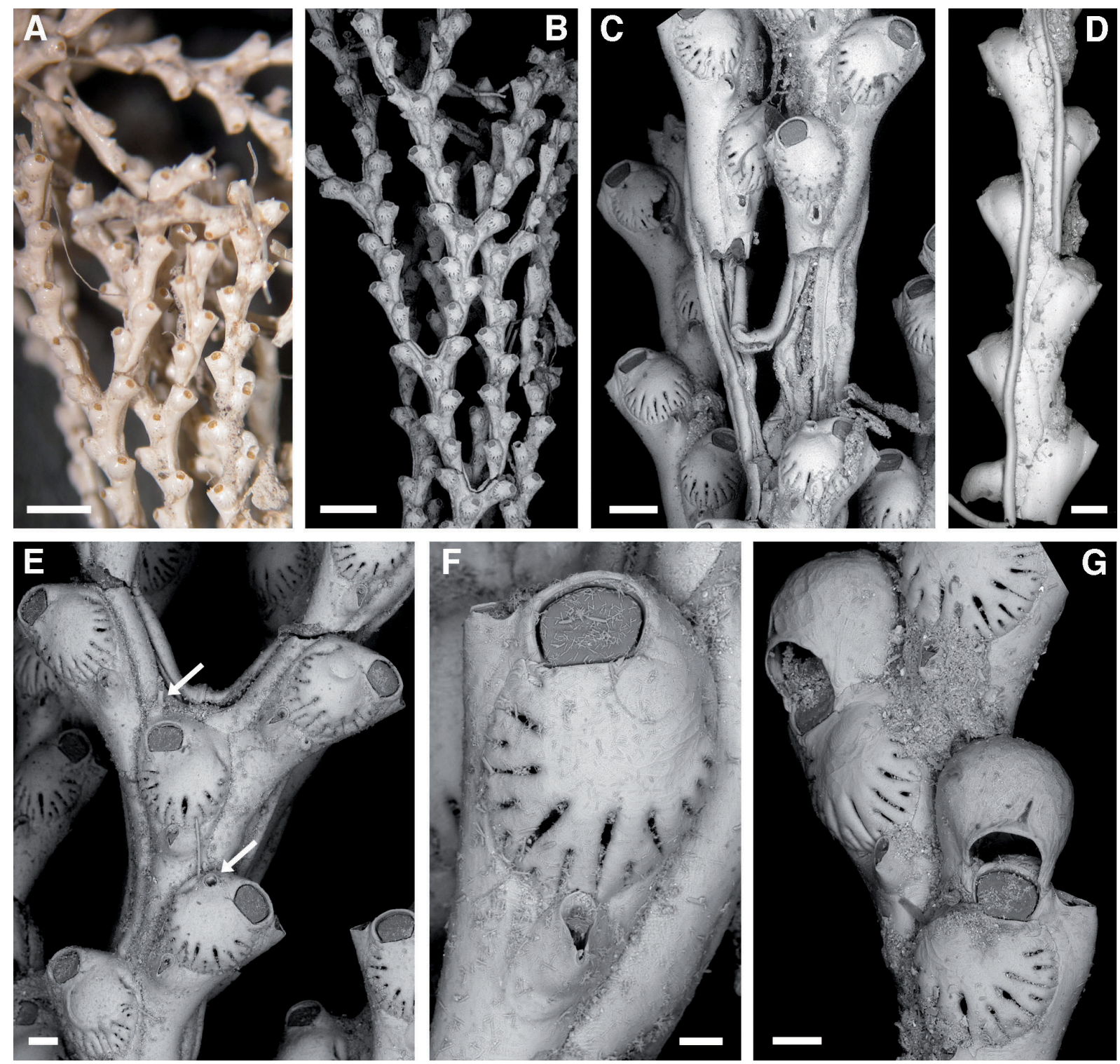

Fig. 1. Notoplites saojorgensis sp. nov. (MNHN 4163, holotype). A. Optical image of colony showing the porcelain white zooecia. B. Overview of colony showing several internodes and branch bifurcations. C. Proximal part of the colony with numerous, closely joined rhizoids emanating from proximal and abfrontal zooids, forming supporting stalks. D. Abfrontal side of internode with two rhizoids. E. Autozooids at branch bifurcation; note the basal part of the greatly enlarged spine at the base of the scutum (lower arrow) and the single spine of normal size in the median zooid at the bifurcation point (upper arrow). F. Close-up of autozooid with distolateral and proximal avicularium. G. Ovicellate zooids; note the proximomedian, acutely triangular window in the ooecium. Scale bars: $\mathrm{A}, \mathrm{B}=1 \mathrm{~mm}$; $\mathrm{C}, \mathrm{D}=200 \mu \mathrm{m} ; \mathrm{E}, \mathrm{G}=100 \mu \mathrm{m} ; \mathrm{F}=50 \mu \mathrm{m}$. 
Table 1. Measurements (in $\mu \mathrm{m}$ ) of skeletal characters of Notoplites saojorgensis sp. nov., taken from the holotype (MNHN 4163). SD = standard deviation, $\mathrm{N}=$ number of measurements.

\begin{tabular}{|c|c|c|c|c|}
\hline & Mean & SD & Range & N \\
\hline Zooid length & 932 & 94 & $748-1104$ & 20 \\
\hline Zooid width & 331 & 25 & $275-378$ & 20 \\
\hline Orifice length & 95 & 4 & $86-103$ & 20 \\
\hline Orifice width & 126 & 8 & $106-144$ & 20 \\
\hline Scutum length & 277 & 16 & $251-314$ & 20 \\
\hline Scutum width & 290 & 21 & $234-335$ & 20 \\
\hline Ooecium length & 322 & 11 & $313-337$ & 4 \\
\hline Ooecium width & 282 & 24 & $248-302$ & 4 \\
\hline Avicularium length & 78 & 7 & $62-87$ & 20 \\
\hline Avicularium width & 40 & 3 & $33-45$ & 20 \\
\hline
\end{tabular}

\section{Paratypes}

Same locality information as holotype: MOM 42 0877, numerous detached internodes; MOM 42 1213, several internodes embedded in Canada balsam on a glass slide.

\section{Description}

Colony erect, jointed, dichotomously branching, forming a delicate tuft of up to $6.5 \mathrm{~cm}$ in height, attached by numerous rhizoids that form a supporting stalk; zoarium porcelain white in dried state (Fig. 1A-C). Branches formed by two series of alternating autozooids, mostly with 4-9 autozooids between bifurcations, zooids opening on one side only (Fig. 1D). Branching points composed of a single proximomedian zooid and two distolateral ones, with the nodes developing immediately distal to the latter zooids by breakage of the narrow proximal parts of the subsequent zooids (Fig. 1E). Autozooids very elongate, narrowest and tubular proximally, widening distally with the distal half of zooids turned outwards at an angle of c. $40^{\circ}$, usually (much) less than half of total autozooid length occupied by the scutum/membranous area and orifice (Fig. 1E-F); skeletal surface smooth, convex, zooids separated by a distinct groove, forming a zigzag line on the abfrontal side (Fig. 1D). Rhizoids produced from a small pore near proximal end on the abfrontal side of some zooids, closely approximated to form a single stalk (Fig. 1C-D).

Orifice slightly raised and displaced towards the outer zooid margin (Fig. 1E), very well-defined, wider than long and widest in distal third, straight proximal margin formed by distal scutum, operculum thickly sclerotised (Fig. 1F). Scutum convex, about as wide as long, distally branched with the branch ends merging with the circum-opesial gymnocyst and covering the membranous area like a well-fitting lid, branches separated by some 14-20 narrow fissures of variable length, some reaching almost half of scutum length (Fig. 1F); scutum originating from a broad inconspicuous base near the inner distal zooid margin just proximolateral to orifice, with the scutum base occasionally bearing a single greatly enlarged spine (Fig. 1E); a smaller single spine distal to orifice only in median zooids at branching points (Fig. $1 \mathrm{E})$.

Two adventitious avicularia of about the same size and shape per zooid (Fig. 1F): one situated lateral to orifice and forming the outer zooid margin, with the triangular rostrum directed outwards and the frontal area more or less distally; the other one situated on a raised cystid just proximally to scutum, with 
the distally slightly downcurved rostrum directed proximally; mandibles in both avicularia hinged on inconspicuous condyles formed by the distal part of an immersed cryptocystal shelf in the proximal area.

Ovicell globular, prominent, the inner half of ooecium resting on the proximal part of the distal zooid, slightly longer than wide, surface somewhat uneven and with a proximomedian elongate-triangular fenestra pointing distally, the proximolateral ooecial margins reaching towards mid-distance of lateral orifice rim, ovicell opening well arched above orifice (Fig. 1G).

An ancestrula was not observed.

\section{Remarks}

There are two species that are closely related to Notoplites saojorgensis sp. nov., the types of both of which have recently been figured and described by Souto et al. (2011): N. marsupiatus (Jullien, 1883), originally recorded from the continental slope of NW Spain, and N. clausus (Busk, 1884), sampled some $400 \mathrm{~km}$ west of the Azores. All three species share the same type of fimbriated scutum.

Notoplites clausus was later considered to be a junior synonym of $N$. marsupiatus by Jullien (1888), Calvet (1907) and other workers. However, Souto et al. (2011) showed that they are distinct species and reinstated $N$. clausus. In turn, Notoplites saojorgensis sp. nov., which was identified as N. marsupiatus by Calvet (1931), is clearly different from these two. The specimens imaged as Scrupocellaria marsupiata by d'Hondt (1975), without any further comments, are very close to $N$. clausus owing to the presence of a distal oral spine, small lateral avicularia, and fewer fissures in the scutum than $N$. saojorgensis sp. nov. However, d'Hondt (1975) recorded the specimens from eight stations: four within the Azores archipelago, two from stations west of the western Azorean islands (i.e., closer to the type location of $N$. clausus), and two from stations several hundred kilometres north of the Azores. While the exact origin of the figured specimens cannot be retraced, it is likely that two or more species were combined under the name $N$. marsupiata in that study. These samples could not be analysed during the present project, as most of them are not present at the MNHN.

Notoplites saojorgensis sp. nov., as most other Notoplites spp., occurs at bathyal depths. The colonies are anchored in soft sediments via a single stalk formed by numerous long rootlets.

Infraorder Flustrina Smitt, 1868

Superfamily Cellarioidea Fleming, 1828

Family Cellariidae Fleming, 1828

Genus Cellaria Ellis \& Solander, 1786

Cellaria harmelini d'Hondt, 1973

Fig. 2, Table 2

Cellaria harmelini d'Hondt, 1973: 374, pl. 1, figs 2-4.

\section{Material examined}

\section{Lectotype (here designated)}

MNHN 6888, Thalassa Stn 436, 4 Aug. 1967, northern Bay of Biscay, 4756’ N-0752.7’ W, 360 m.

\section{Paralectotype (here designated)}

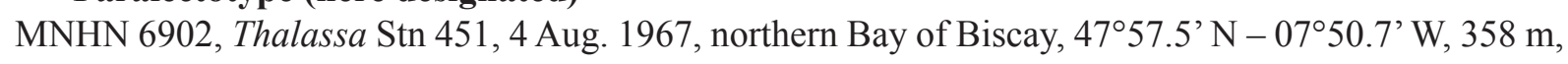
on hydroids. 
When introducing this species, d'Hondt (1973) did not indicate type material. The subsequent listing of the "holotype" and "paratype" of Cellaria harmelini without further information in a catalogue of the potential type specimens kept at the MNHN (Tricart \& d'Hondt 2009) violates Article 73.1.3. of the ICZN Code (ICZN 1999). Therefore, the lectotype and paralectotype are formally designated here for the "holotype" and "paratype", respectively, of Tricart \& d'Hondt (2009).

\section{Description}

Colony erect, flexible, dichotomously branching, about $3 \mathrm{~cm}$ in height and composed of 6-7 internodes; internodes slender (Fig. 2A), cylindrical, composed of 6 alternating longitudinal series of zooecia (4 in one horizontal row), basal internodes some $2-4 \mathrm{~mm}$ long, distal ones up to $8-9 \mathrm{~mm}$ in length, with 1 or 2 fertile zones per internode producing distinctly thicker $(c a .0 .7-0.9 \mathrm{~mm})$ segments, zooecia separated by a thin ridge flanked by a shallow groove on each side. Autozooecia in sterile segments elongated subhexagonal (Fig. 2B), successive zooecia in a series not in direct contact and being well spaced, contact with lateral neighbours in the next series after the alternating one along a straight boundary, proximal zooecial margin V-shaped. Fertile zooecia elongated hexagonal, about as long and wide as sterile zooecia, in direct contact with the successive zooecia in the same series and with those in the alternating neighbour-series, proximal zooidal margin usually straight (Fig. 2D). Central cryptocyst depressed, framed by a pair of longitudinal ridges reaching from the distolateral zooecium margin lateral to opesia toward proximal part of zooecium, where they level with the depressed cryptocyst (Fig. 2B); cryptocyst smooth in autozooecia, in fertile zooecia granular along zooecial margins, particularly so proximally and distally. Opesia semi-elliptical, broader than long, proximal edge convex with a pointed
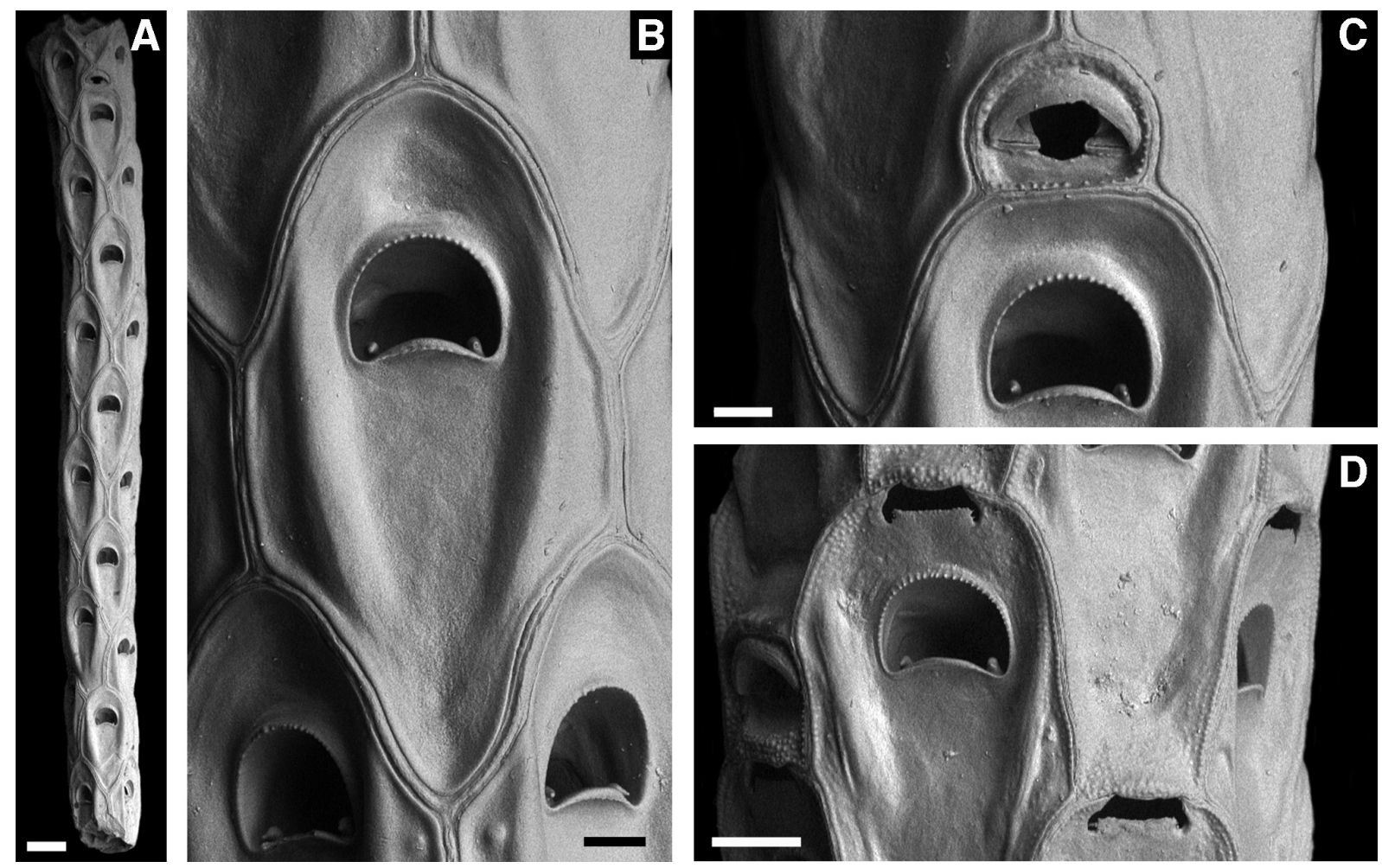

Fig. 2. Cellaria harmelini d'Hondt, 1973 (MNHN 6902, paralectotype). A. Overview of an infertile internode with a distal avicularium. B. Close-up of an autozooecium. C. An avicularium situated distal to an autozooecium. D. Ovicellate zooecia, one with a distal avicularium at left. Scale bars: A $=200 \mu \mathrm{m}$; $\mathrm{B}, \mathrm{C}=50 \mu \mathrm{m} ; \mathrm{D}=100 \mu \mathrm{m}$. 
Table 2. Measurements (in $\mu \mathrm{m}$ ) of skeletal characters of Cellaria harmelini d'Hondt, 1973, taken from the paralectotype (MNHN 6902). $\mathrm{SD}=$ standard deviation, $\mathrm{N}=$ number of measurements.

\begin{tabular}{|c|c|c|c|c|}
\hline & Mean & SD & Range & N \\
\hline Length of sterile zooecia & 611 & 38 & $551-659$ & 8 \\
\hline Width of sterile zooecia & 300 & 25 & $270-325$ & 8 \\
\hline Opesia length & 98 & 6 & $86-107$ & 16 \\
\hline Opesia width & 129 & 8 & $115-144$ & 16 \\
\hline Ooecium length & 41 & - & $40-42$ & 3 \\
\hline Ooecium width & 109 & - & $104-115$ & 3 \\
\hline Avicularium length & 123 & - & $120-125$ & 2 \\
\hline Avicularium width & 158 & - & $154-162$ & 2 \\
\hline Diameter of sterile branch part & 442 & 41 & $376-505$ & 10 \\
\hline Diameter of fertile branch part & 690 & - & - & 1 \\
\hline
\end{tabular}

denticle near each corner that is bent at a $90^{\circ}$ angle and directed terminally, distal opesial rim finely beaded, proximal rim occasionally very faintly beaded (Fig. 2B-D).

Opening of fully formed ooecia roughly trapezoidal (Fig. 2D), very short and broad, situated at the maternal zooid's extreme distal end, with the proximal cryptocyst of the succeeding zooecium or avicularium forming the distal margin of the ooecium, slightly less than proximal half occluded by a square plate with small lateral denticles extending from its lateral edges; "ooecial" opening in zooecia situated in proximal parts of the thickened fertile internodal zones, subrounded, placed between opesia and distal zooecium margin and therefore less distal than in fully formed ooecia.

Avicularium of fistulosa-type (Fig. 2C), situated directly distal to a zooecium, proximal border straight and the distolateral outline forming two-thirds of a full circle in sterile internodal zones and with a rather square outline in fertile zones, both forms slightly broader than long. Proximal cryptocyst in autozoocial zones short and smooth, extremely reduced distolaterally, thin margin granular all around, proximal cryptocyst in fertile zones slightly more extensive and granular; rostrum semicircular, arched and very slightly raised with straight proximolateral edges extending into the subcircular opesia, directed distally or distolaterally.

Perforations for rhizoidal kenozooids were not observed.

\section{Remarks}

Almost all of the species' characters were already given by d'Hondt (1973) in the original description in French, which are largely transcribed here. However, whereas some SEM photos of general zoarial features were given in that publication, images of cleaned zooecia were not provided.

The new measurements given above occasionally differ from those in the original account. Whereas some of these differences may be due either to the few internodes available in the present study and/or to the use of different measuring techniques (optical with a microscope vs. digital from SEM images), other values in the original paper seem unrealistic. For instance, significant morphometric differences in zooecium and opesia dimensions between fertile and sterile zooecia, as stated by d'Hondt (1973), could not be affirmed in the paralectotype studied. 
Cellaria harmelini was subsequently reported by Hayward (1978) and Hayward \& Ryland (1978) from several other stations along the northern shelf margin of the Bay of Biscay, whereas d'Hondt (1973) recorded the species also from a location in the southern Bay of Biscay $\left(44^{\circ} 01.6^{\prime} \mathrm{N}-07^{\circ} 01.9^{\prime} \mathrm{W}, 510\right.$ $630 \mathrm{~m}$ ). Most samples were taken from gravelly sediment surfaces, and the species' depth of occurrence ranges from 180 to $700 \mathrm{~m}$.

The status of Cellaria harmelini subsp. tenuis d'Hondt, 1974, recorded from the northern and northwestern Spanish shelf edge, cannot be commented on at present.

\author{
Infraorder Ascophorina Levinsen, 1909 \\ "Grade" Umbonulomorpha Gordon, 1989 \\ Superfamily Lepralielloidea Vigneaux, 1949 \\ Family Romancheinidae Jullien, 1888
}

Genus Hippomenella Canu \& Bassler, 1917

Hippomenella Canu \& Bassler, 1917: 41.

Hippomenella - Brown 1949: 517. — Harmer 1957: 1095. — Gordon 1984: 77. — Zabala \& Maluquer 1988: 117.

\title{
Type species
}

Lepralia mucronelliformis Waters, 1899, by original designation.

\section{Diagnosis (amended)}

Colonies encrusting, budding intrazooidal. Frontal shield partly umbonuloid, with two or more rows of lateral areolar pores encircling an imperforate suboral area; basal pore chambers with multiporous septula. Orifice with condyles, oral spines present. Ovicell hyperstomial, ectooecium uncalcified, endooecial surface finely pitted in parts but devoid of any other structures, not closed by the operculum. Adventitious avicularia present, occasionally dimorphic.

\section{Remarks}

Since its introduction, the genus Hippomenella has been assigned to a number of different families. The confusion stems from the fact that the original generic diagnosis by Canu \& Bassler (1917) included characters of several superficially similar, yet structurally distinct, Recent and fossil species, resulting in a poorly defined genus. Although Brown (1949) noticed this problem and described the lectotype of Hippomenella mucronelliformis in great detail, the type species still remained relatively poorly known, as SEM images have never been published to date.

The genus has previously been placed in the schizoporelloid families Hippoporinidae Osburn, 1952 (Brown 1958: 62), Hippopodinidae Levinsen, 1909 (Gordon 1984: 77), Schizoporellidae Jullien, 1883 (Gordon 1989: 43; Gordon et al. 1994; Gordon \& d'Hondt 1997: 25), and very recently in the Escharinidae Tilbrook, 2006 (D.P. Gordon, pers. comm. 2011). Tilbrook (2006) and Hayward \& Winston (2011) regarded Hippomenella as incertae sedis. After SEM analysis of the lectotype of H. mucronelliformis the generic diagnosis is here revised, and the genus transferred to the lepralielloid family Romancheinidae Jullien, 1888 for reasons specified below. Thus, Hippomenella is now being united with the genus Waters (1899) initially considered closely related: the species epithet mucronelliformis refers to its similarity with Mucronella coccinea Abildgaard, 1806, which today is placed in the romancheinid genus Escharoides Milne Edwards, 1836. 
The presence of a ring scar (Fig. 3E), which defines the slightly reduced central umbonuloid part of the frontal shield in the type species, is one reason for removing the genus from the lepraliomorph Escharinidae to the umbonulomorph Romancheinidae. The previous assignment of Hippomenella to lepraliomorph families was partly due to its original placing in the Hippoporininae by Canu \& Bassler (1917) [see the discussion on this subfamily and the family Hippoporinidae in Gordon (1984); both taxa are now considered as synonyms of Phidoloporidae Gabb \& Horn, 1862]. Moreover, Brown (1949, 1952) and Gordon (1984) considered the New Zealand species Lepralia vellicata Hutton, 1873 to belong to Hippomenella. Despite the apparently similar structure of the frontal shield at the zooidal surface, Gordon (1984: 77) observed that the imperforate umbonuloid part of the shield of $L$. vellicata is extremely reduced, which was considered by him to support a placing of the genus in the Lepraliomorpha. The numerous pores along the marginal frontal shield of the above-mentioned species are all considered here to be areolar pores, as more than one may contribute to avicularium formation. The presence of over 20 avicularia that are scattered on the surface of a single zooid of $L$. vellicata ( $c f$. Brown 1949: 519) supports this interpretation.

The other major source of confusion was a misconception of the ooecium structure of Hippomenella. The ooecium of $H$. mucronelliformis was not known when Canu \& Bassler (1917) introduced the genus. Instead they described the ooecia of species that may be placed in the morphologically similar romancheinid genus Hippopleurifera Canu \& Bassler, 1925 (see discussion in Hastings 1966), the genotype of which (Eschara biauriculata Reuss, 1847) is characterised by a pair of lateral fenestrae in the ooecium. Moreover, Brown (1949) considered the endooecium to be entirely perforated by pseudopores, and, based on observations of L. vellicata, Gordon (pers. comm. 2012) later regarded the ooecium type of Hippomenella as schizoporelloid. Thus, a number of species with a range of ooecial structures and morphologies were lumped together in Hippomenella. In contrast, in H. mucronelliformis the calcified endooecium is not perforated by pseudopores (as in the schizoporelloid type) but merely superficially pitted in the distolateral part (Fig. 3C, F), and it is lacking any other ooecial structures.

This ovicell type is, in turn, rather similar to the primary ooecium in the genus Escharoides, and therefore yet another argument for placing Hippomenella in the Romancheinidae. Prior to being covered by secondary calcification of the distal zooid, the endooecium in Escharoides shows a similarly pitted surface as in H. mucronelliformis. This can best be seen in fossil specimens of Escharoides in which the (presumably aragonitic) secondary calcification has vanished (see Berning 2006: figs 71, 73-79).

Comparative analyses of the frontal shield (e.g., the extent of the umbonuloid part) and the ooecium will be vital in order to unravel the relationship between Hippomenella and Hippopleurifera. For instance, in the genotype of Hippopleurifera almost the entire frontal shield is perforated by areolar pores, suggesting that the umbonuloid part is extremely reduced. The ooecial fenestrae in Hippopleurifera supposedly result from a thick but incomplete cover of secondary calcification produced by the distal zooid, whereas the exposed endooecium is densely perforated by tiny pseudopores or superficial pits. In contrast, in several other (fossil) species that have been assigned to Hippopleurifera the extent of the umbonuloid frontal shield seems to be similarly extensive as in H. mucronelliformis, and there is no secondary calcification from the distal zooid covering the imperforate endooecium. The occasionally occurring prominent ribs in some of these species (e.g., in the Pliocene Eschara sedgwicki Milne Edwards, 1836) are probably entirely of endooecial origin. Additionally, a third group comprises species with apparently schizoporelloid-like ovicells, i.e., with pseudopores that penetrate the endooecium (e.g., L. vellicata, Hippomenella amaralae Vieira et al., 2010, Hippopleurifera belizae Winston, 1984, Hippomenella ramula Hayward \& Winston, 2011). A thorough revision of these taxa is, therefore, urgently needed but beyond the scope of the present paper. For this reason, the generic diagnosis given above is rather conservative and may need to be expanded again if species with other ooecial structures are included in Hippomenella. 
Information on the ancestrula has also been omitted from the generic diagnosis because I doubt that the zooid identified and described as such by Brown (1949), which looks similar to a mature autozooid but with more proximally positioned avicularia (Fig. 3A), is indeed the ancestrula. In the type specimen (and also observed in another colony) the region immediately proximal to and around this zooid is occupied by other autozooids, which probably cover and disguise the true ancestrula. In fact, remnants of spines of the true ancestrula can still be seen that are situated close to the proximal margin of the first generation autozooid and which are not entirely covered by the overgrowing zooid. As all other romancheinid taxa have a tatiform ancestrula, I presume the same applies to Hippomenella.

Hippomenella mucronelliformis (Waters, 1899)

Fig. 3, Table 3

Lepralia mucronelliformis Waters, 1899: 11, pl. 3, figs 15, 21.

Lepralia mucronelliformis - Norman 1909: 306.

Hippomenella mucronelliformis - Brown 1949: 513, figs 1, 2a,b,d,e.

\section{Material examined}

\section{Lectotype}

MM 3780 (here designated), Madeira (no further information provided as to the exact location or depth), on bivalve fragment, mounted on slide, Waters collection.

\section{Paralectotype}

MMF 42297 (here designated), Madeira (no further information provided as to the exact location or depth), on bivalve fragment, mounted on slide, J.Y. Johnson collection.

\section{Other material}

MM 3781, Madeira (no further information provided as to the exact location or depth), opercula, in Canada balsam on slide, Waters collection; NHMUK 1947.8.12.1, Madeira (no further information provided as to the exact location or depth), two colonies on bivalve shell fragments and several isolated zooids mounted on slide, from the Canon J. de G. Barreto collection.

Although Brown (1949) stated that the lectotype was chosen by Norman (1909: 306), this author simply mentioned that he had "seen the type". This may not violate Article 74.5 of the ICZN Code (ICZN 1999), and may represent a valid designation of the lectotype. However, it is unclear exactly what specimen Norman had seen: the colony now kept at Manchester Museum or that from the Funchal Museum. Both specimens carry identical labels and the handwriting of Waters, and are clearly syntypes. Moreover, the slide from the MMF, which was considered by Brown to contain the type specimen, originally comprised two colonies, judging from the remains of glue in the slide cavity, whereas neither Waters (1899) nor Norman (1909) explicitly mentioned how many specimens they were referring to. A small green label on MM 3780 indicates that this specimen was figured by Waters (a single autozooid; pl. 3, fig. 21), whereas a green and red label on MM 3781 denotes this specimen (supposedly containing opercula) as the figured type specimen (Pl. 3, Fig. 15). However, it is unclear from which colony the opercula were taken; more importantly, there is not a single operculum present on the slide today. They have either decayed or been lost, as one edge of the cover slide is shattered. This specimen must, therefore, not be regarded as a type.

To conclude, I disregard Brown's (1949) statement that "the type" had been chosen by Norman (1909), and designate as lectotype of $H$. mucronelliformis the figured specimen MM 3780. The only remaining syntype specimen on the slide of sample MMF 42297 becomes the paralectotype. 

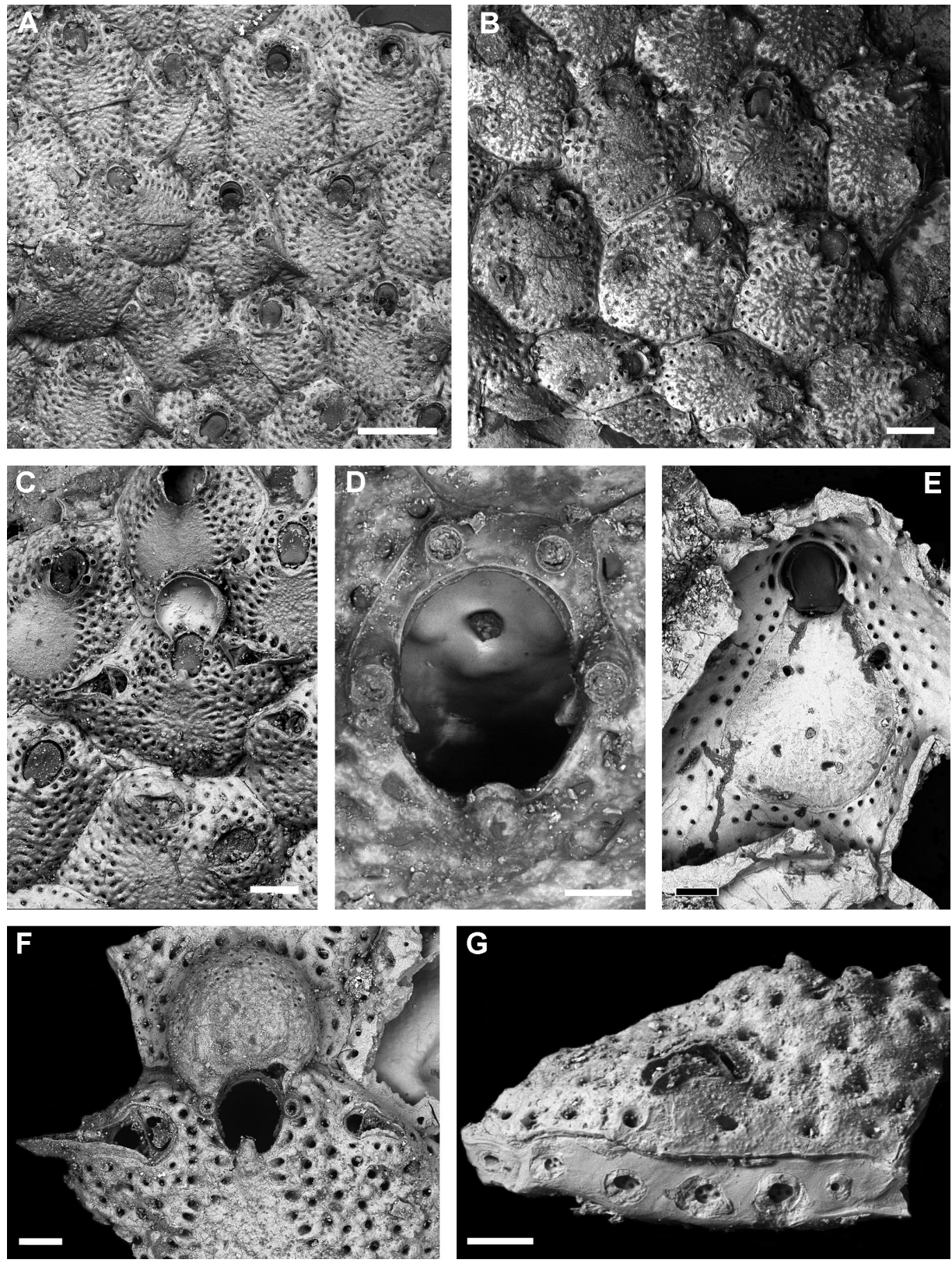

Fig. 3. Hippomenella mucronelliformis (Waters, 1899). A. Overview of autozooids in the lectotype (MM 3780); note the extremely long and slender mandibles of the small avicularia. B. Early astogenetic part of the paralectotype (MMF 42297), including the zooid interpreted by Brown (1949) to be the ancestrula (at lower left) but which is here considered as the first autozooid; note that the avicularia in early astogenetic zooids are proximally positioned and directed. C. Autozooids and an ovicellate zooid at the colony margin; note that the forming endooecium is not perforated by pseudopores and that the suboral mucro is absent in early ontogenetic zooids, forming only during later ontogeny (NHMUK 1947.8.12.1; photo: M.E. Spencer Jones). D. Close up of orifice (lectotype, MM 3780). E. Interior frontal shield with the umbonuloid ring-scar framed by areolar pores (NHMUK 1947.8.12.1; photo: M.E. Spencer Jones). F. Ovicellate zooid; note the superficial pits on the distolateral endooecium (NHMUK 1947.8.12.1; photo: M.E. Spencer Jones). G. Lateral view of a zooid (distal is to the right), showing five multiporous pore plates in the vertical wall (NHMUK 1947.8.12.1; photo: K.J. Tilbrook). Scale bars: A $=400 \mu \mathrm{m}$; B, $\mathrm{C}=200 \mu \mathrm{m} ; \mathrm{D}=50 \mu \mathrm{m} ; \mathrm{E}, \mathrm{F}, \mathrm{G}=100 \mu \mathrm{m}$. 
Table 3. Measurements (in $\mu \mathrm{m}$ ) of skeletal characters of Hippomenella mucronelliformis (Waters, 1899), taken from specimens MM 3780 (lectotype), MMF 42297 (paralectotype) and NHMUK 1947.8.12.1. $\mathrm{SD}=$ standard deviation, $\mathrm{N}=$ number of measurements.

\begin{tabular}{|c|c|c|c|c|}
\hline & Mean & SD & Range & N \\
\hline Zooid length & 755 & 83 & $618-922$ & 20 \\
\hline Zooid width & 640 & 100 & $441-820$ & 20 \\
\hline Orifice length & 168 & 13 & $134-190$ & 20 \\
\hline Orifice width & 133 & 13 & $113-168$ & 20 \\
\hline Ooecium length & 303 & - & $275-350$ & 3 \\
\hline Ooecium width & 342 & - & $310-370$ & 3 \\
\hline Length of small avicularium & 128 & 22 & $83-176$ & 20 \\
\hline Width of small avicularium & 63 & 11 & $41-89$ & 20 \\
\hline Length of large avicularium & 321 & 47 & $206-402$ & 20 \\
\hline Width of large avicularium & 133 & 16 & $97-157$ & 20 \\
\hline
\end{tabular}

\section{Description}

Colony encrusting, unilaminar, multiserial, forming small patches. Zooecia relatively large, subhexagonal, widest at about mid-distance, occasionally wider than long, separated by deep furrows (Fig. 3A-C); communication between zooids via up to 5 multiporous pore plates per neighbouring zooid (Fig. 3G). Frontal shield slightly convex proximally, somewhat raising distally towards orifice, secondary calcification forming a blunt prominent suboral mucro during ontogeny (Fig. 3C, D), surface rugose to nodular, central drop-shaped area imperforate, demarcated by a row of densely spaced areolar pores with radially aligned intervening ridges indicating the extent of the central umbonuloid part of the frontal shield (Fig. 3C, E), 1-3 additional rows of widely-spaced pores in the external area towards zooid margin, particularly abundant proximolateral of orifice with 1-2 rows extending between orifice and distal zooecial margin (Fig. 3C). Orifice elongate oval, longer than wide and usually widest in distal third, proximolateral edges rounded, the slightly concave proximal margin covered by the overarching and distally pointing mucro, blunt condyles formed by a continuation and slight inbending of lateral orifice margins, directed proximomedially and delimiting the proximal fourth or fifth of total orifice length (Fig. 3D); operculum strongly sclerotised with a pair of lateral ridges where muscles attach; usually 6 (range 4-7, in early astogenetic zooids up to 9) oral spines along distolateral orifice margin, the proximal pair slightly larger, two in ovicellate zooids (Fig. 3A, B, F).

Ooecium hyperstomial, depressed globular, slightly wider than long, endooecial surface fairly smooth, imperforate but distolaterally with numerous small round pits (Fig. 3F), proximal ooecial margin concave, shallowly arched, reaching towards lateral orifice rim, not closed by the operculum.

Avicularia adventitious, dimorphic, usually paired (Fig. 3F), occasionally single, rarely absent, situated lateral or proximolateral to orifice at zooid margin, directed laterally or proximolaterally except in early astogenetic zooids where the rostrum points proximally and the avicularia are more proximally positioned (Fig. 3B); small avicularium with a relatively short, proximally incurved rostrum, distally parallel-sided, downcurved and chute-like with open end, mandible thin and elongate, up to four times the length of rostrum (Fig. 3A); often one avicularium or sometimes both greatly enlarged, their width usually exceeding length of smaller avicularia (Fig. 3C, F), positioned on a slightly enlarged perforated cystid, rostrum proximally incurved, distally thin and parallel-sided with an acute downcurved tip, reaching 
over the lateral zooid's frontal shield, mandible confined to rostrum; crossbar in both avicularium types complete without columella, proximal opesia semicircular.

Ancestrula not observed.

\section{Remarks}

Apart from its type location at Madeira, H. mucronelliformis has been reported from NW Morocco by Canu \& Bassler (1925: 30) as well as from the Mediterranean Sea by Harmelin (1969: 1208, figs 6-9), Hayward (1974: 371), Zabala (1986: 407, text-fig. 134, pl. 6, figs B, C), and Zabala \& Maluquer (1988: 117, text-fig. 244, pl. 8, fig. H), from depths down to $200 \mathrm{~m}$. However, most of these works lack a thorough description and illustration, and because some of these records differ in a few aspects from the type, I have only included the records from Madeira in the synonymy list. For instance, in at least some of the specimens recorded by Zabala (1986) and Zabala \& Maluquer (1988) from the Western Mediterranean, the suboral mucro is not developed or only very reduced, as can be seen in the provided SEM images. In turn, the orifice of the specimen from the Eastern Mediterranean Sea imaged by Harmelin (1969) has medially pointing condyles. Therefore, these records need to be checked for conspecifity based on SEM observations.

There are also several fossil specimens that have been recorded as $H$. mucronelliformis. Those from the Pliocene of Sicily (Pouyet \& Moissette 1992: 62, pl. 9, fig. 9) very much resemble the Recent type, whereas the Middle Miocene specimens from the Paratethys are similar but probably represent a distinct species, as they have a slightly different orifice shape and the proximal ooecial margin is rimmed (Zágorsek 2010: 168, pl. 143, figs 1-4). These records show that the genus Hippomenella has a considerable fossil history in the Paratethys, and also that the Atlantic-Macaronesian region may have played an important role in acting as a refuge for Paratethyan-Mediterranean bryozoan taxa during the Messinian salinity crisis and/or the Pleistocene temperature minima (e.g., Berning 2006). Similar temporal and geographic distribution patterns were recently reported in species of the cheilostome genera Saevitella Bobies, 1956 and Calloporina Neviani, 1895 (see Berning 2012).

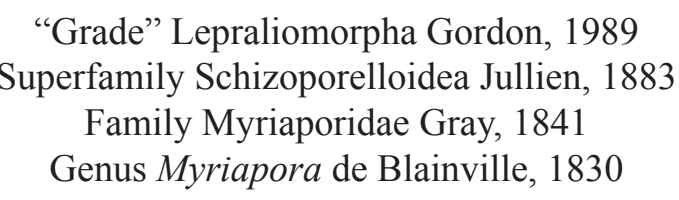

Myriapora bugei d'Hondt, 1975

Fig. 4, Table 4

Myriapora bugei d'Hondt, 1975: 585, figs 23, 25-28.

non Myriapora bugei - El Hajjaji 1992: 250, pl. 15, figs 14-15.

\section{Material examined}

Lectotype (here designated)

MNHN IB-2013-3, one dried colony fragment (former part of MNHN 7481), Jean Charcot, Biaçores

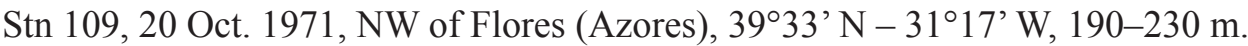

Paralectotypes (here designated)

MNHN 7481, Jean Charcot, Biaçores Stn 109, 20 Oct. 1971, NW of Flores (Azores), 39³3' N - 31 ${ }^{\circ} 17^{\prime}$ W, 190-230 m; MNHN IB-2013-2, one dried colony fragment (former part of MNHN 7492), Jean Charcot, Biaçores Stn 110, 20 Oct. 1971, NW of Flores (Azores), 39³ ' $\mathrm{N}-31^{\circ} 17.5^{\prime} \mathrm{W}, 300-350 \mathrm{~m}$; MNHN 7482, 13 colony fragments in ethanol, Jean Charcot, Biaçores Stn 109, 20 Oct. 1971, NW of 
Flores (Azores), 39 33' N - 31 '17' W, 190-230 m; MNHN 7488, one colony fragment in ethanol, Jean Charcot, Biaçores Stn 110, 20 Oct. 1971, NW of Flores (Azores), 39³3' N - 31 ${ }^{\circ} 17.5^{\prime}$ W, 300-350 m; MNHN 7492, four colony fragments in ethanol, Jean Charcot, Biaçores Stn 110, 20 Oct. 1971, NW of Flores (Azores), $39^{\circ} 33^{\prime} \mathrm{N}-31^{\circ} 17.5^{\prime} \mathrm{W}, 300-350 \mathrm{~m}$.
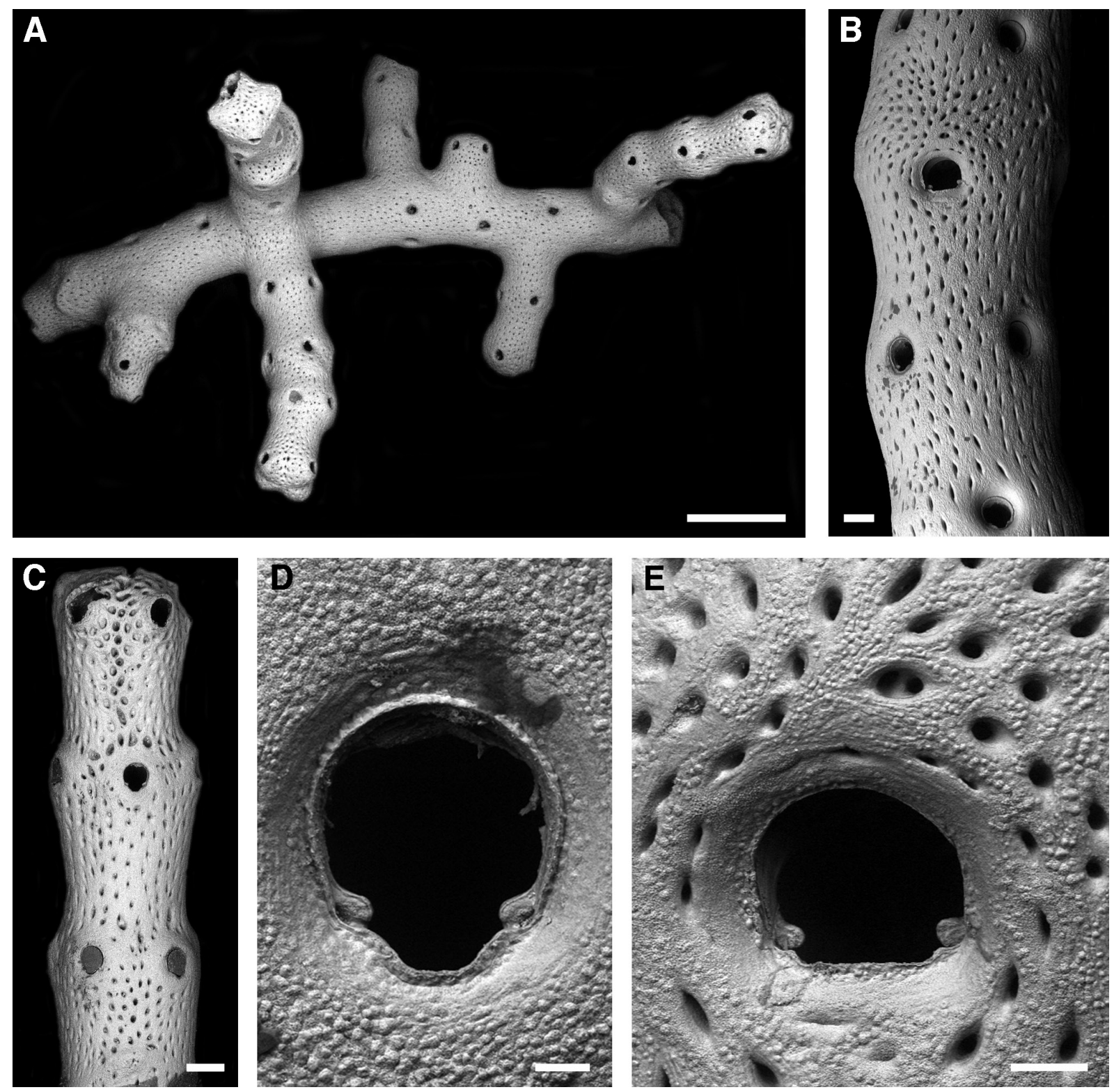

Fig. 4. Myriapora bugei d'Hondt, 1975. A. Colony fragment with closely spaced branches bifurcating at a $90^{\circ}$ angle from the main branch (MNHN IB-2013-3, lectotype). B. Branch segment with one whorl of fertile zooecia at top, identified by the larger dimorphic orifice and the radial arrangement of pseudopores (MNHN IB-2013-2, paralectotype). C. Distal branch with early ontogenetic autozooecia (MNHN 7481, paralectotype). D. Close-up of an autozooecial orifice (MNHN IB-2013-2, paralectotype). E. The dimorphic orifice of a maternal zooecium (MNHN IB-2013-2, paralectotype). Scale bars: A = $2 \mathrm{~mm}$; B $=200 \mu \mathrm{m} ; \mathrm{C}=300 \mu \mathrm{m} ; \mathrm{D}=50 \mu \mathrm{m} ; \mathrm{E}=100 \mu \mathrm{m}$. 
Table 4. Measurements (in $\mu \mathrm{m}$ ) of skeletal characters of Myriapora bugei d'Hondt, 1975, taken from specimens MNHN IB-2013-3 (lectotype), MNHN 7481 (paralectotype), and MNHN IB-2013-2 (paralectotype). Branch width was measured on relatively mature branch regions; younger ones are distinctly narrower. As skeletal boundaries are invisible on the colony surface, ooecium dimensions could not be measured. $\mathrm{SD}=$ standard deviation, $\mathrm{N}=$ number of measurements.

\begin{tabular}{|c|c|c|c|c|}
\hline & Mean & SD & Range & N \\
\hline Longitudinal distance between centroids of orifices & 1337 & 113 & $1197-1541$ & 15 \\
\hline Lateral distance between centroids of orifices & 741 & 94 & $643-908$ & 9 \\
\hline Orifice length in sterile zooecia & 227 & 9 & $216-240$ & 8 \\
\hline Orifice width in sterile zooecia & 199 & 9 & $183-211$ & 8 \\
\hline Orifice length in maternal zooecia & 227 & - & - & 1 \\
\hline Orifice width in maternal zooecia & 266 & - & - & 1 \\
\hline Branch diameter & 1367 & 118 & $1176-1531$ & 20 \\
\hline
\end{tabular}

The original material available to d'Hondt (1975: 560) was from Biaçores stations 109 and 110. However, he did not indicate type material when introducing Myriapora bugei, and the figured specimen (figs 23, 25-28) was subsequently destroyed (J.-L. d'Hondt pers. comm. 2012). For the same reasons as stated in the Material section for Cellaria harmelini (see above), the type specimens of M. bugei were invalidly considered as "holotype" and "paratypes" by Tricart \& d'Hondt (2009), and are formally designated here as lectotype and paralectotypes, respectively.

\section{Description}

Colony erect, rigid, delicate branching, producing lateral offsets at an angle of about $90^{\circ}$ at irregular intervals (Fig. 4A). Branches long (3-4 cm), slender and cylindrical, with the zooids opening all around. Zooids large, radially arranged in distinct whorls of 4 (rarely 5), with all orifices at same level and the distal whorl ideally alternating (Fig. 4B-C); zooecia elongate rectangular but boundaries invisible on colony surface. Frontal shield of mature zooecia gently raising towards orifice, giving distal branches an undulating morphology that is slightly reduced due to frontal calcification during ontogeny (Fig. 4AC); frontal shield regularly perforated by numerous elongate pores in spindle-shaped depressions that are longitudinally aligned (Fig. 4B), surface finely granular (Fig. 4D-E). Primary orifice dimorphic; in autozooids slightly longer than wide (Fig. 4D), anter horseshoe-shaped, widest slightly distal to middistance, proximolateral corners rounded with the short shoulders slightly sloping towards a deep and broadly U-shaped sinus occupying about two-thirds of total proximal width, condyles conspicuous, broad and with rounded edges, not extending beyond shoulders of the proximolateral margin; orifice in ovicellate zooids D-shaped (Fig. 4E), of similar length as in autozooids but especially the proximal margin distinctly broader, sinus a very shallow straight edge comprising four-fifths of total proximal width, proximolateral shoulders thus relatively short and fairly straight, condyles similar to those in autozooids; orifice becoming immersed by frontal calcification and occasionally closed during ontogeny in proximal branch regions, in which case a small short peristome with a central pore remains. No oral spines.

Ovicells relatively rare, present in all zooids of certain whorls, indicated by a slightly thicker swelling of this branch region and by frontal pseudopores that are radially arranged from the proximal ooecium centre (Fig. 4B, E), ooecium mostly incorporated into frontal shields of the distal zooids, surface as frontal shield of zooecia, boundaries invisible at colony surface, ovicell aperture at an acute angle to frontal plane, closure of the cleithral or subcleithral type. 
No avicularia.

An ancestrula was not present in the available material.

\section{Remarks}

Although the genus Myriapora comprises only a few species globally, owing to their mostly erect and conspicuous colonies, and because of the ubiquitous Mediterranean species M. truncata (Pallas, 1766), this bryozoan genus has received a fair amount of attention (e.g., Viskova 1986; Berning 2007; Ferretti et al. 2007; Rodolfo-Metalpa et al. 2010). Besides M. truncata and the polar M. subgracilis (d'Orbigny, 1852), M. bugei is the only other known species from the northern Atlantic realm. The most obvious difference between $M$. bugei and M. truncata is that in the former the branches are composed of distinct whorls whereas zooecia in the latter are ideally alternating, i.e., apparently arranged in spirals around the branch axis. The ooecia and dimorphic orifices of $M$. bugei are here described and figured for the first time.

Originally described from the Azores, the species has also been recorded from the Great Meteor Bank (Piepenburg \& Müller 2004: 61), which is located some $800 \mathrm{~km}$ south of the archipelago. However, although the characters are variable and overlapping to some extent, the populations from the Great Meteor Bank, as well as from the nearby Hyères and Irving seamounts, slightly differ from the type of $M$. bugei in having branches that predominantly consist of five zooids per whorl (occasionally four or six), smaller autozooids, and a narrower autozooecial sinus (pers. observation). Thus, especially considering the distance between the Azores and the seamounts, it is likely that these populations represent distinct species, although genetic studies may be needed to clarify this issue.

In the Azores, M. bugei was reported from depths between 190 and $1235 \mathrm{~m}$ (d'Hondt 1975). It occurs on rocky, gravelly, sandy and muddy substrata growing on rocks, dead corals and bivalve shells.

The specimens El Hajjaji (1992) described and figured as M. bugei from the Late Miocene of NE Morocco (Mediterranean Sea) are similar to the type but certainly belong to a different species due to a distinctly narrower sinus and larger condyles. The status of other coeval specimens from NW Morocco (Atlantic) cannot be assessed, as a detailed description or figures were not provided by Sefian et al. (1999: 242).

Superfamily Mamilloporoidea Canu \& Bassler, 1927

Family Cleidochasmatidae Cheetham \& Sandberg, 1964

Genus Characodoma Maplestone, 1900

Characodoma strangulatum (Calvet, 1906)

Fig. 5, Table 5

Myriozoum strangulatum Calvet, 1906: 158.

Myriozoum strangulatum - Calvet 1907: 427, pl. 26, figs 11-12.

Cleidochasma strangulatum - Harmelin 1977: 1067, text-fig. 25, pl. 2, figs 1, 4, 7. - Harmelin \& d'Hondt 1992: 29.

Characodoma strangulatum - Rosso 1999: 429.

\section{Material examined}

Syntype series

MNHN 492, a single colony fragment on slide, Travailleur Dr. 49, 7 Aug. 1882, Canary Islands, $29^{\circ} \mathrm{N}-$ $16^{\circ} 08^{\prime}$ W, 3700 m; MNHN 493, a single colony fragment on slide, Travailleur Dr. 38, 30 Jul. 1882, NW Morocco, 34 $13^{\prime} 30^{\prime \prime} \mathrm{N}-07^{\circ} 43^{\prime} \mathrm{W}, 636 \mathrm{~m}$; MNHN 947, a single colony fragment on slide, Travailleur 
Dr. 38, 30 Jul. 1882, NW Morocco, 34¹3'30” N - 0743' W, 636 m; MNHN 2471, a single colony fragment on slide, Talisman Dr. 96, 15 Jul. 1883, off Cap d'Arguin (Mauritania), $19^{\circ} 18^{\prime} \mathrm{N}-18^{\circ} 01^{\prime}$ 'W, $2330 \mathrm{~m}$.

\section{Other material}

MNHN 15487, several colony fragments, Balgim DW07, 29 May 1984, SW Portugal, 3646.1' 'N - 9²7' W, 1139-1144 m; MNHN 19804, several colony fragments, Balgim CP92, 8 Jun. 1984, NW Morocco, $34^{\circ} 24.3^{\prime} \mathrm{N}-7^{\circ} 30.3^{\prime} \mathrm{W}, 1182 \mathrm{~m}$.

While clearly stating that the original material comprised specimens from the Travailleur (stations Dr. $38,49)$ and Talisman (station Dr. 96) cruises, Calvet $(1906,1907)$ did not indicate type specimens when introducing Myriozoum strangulatum. The listing of MNHN 2471 as "lectotype" by Tricart \& d'Hondt (2009) was obviously for mere curatorial purposes and violates Article 74.7.3 (see also Declaration 44) of the ICZN Code. This designation is thus considered invalid. For reasons given below, I refrain here from choosing as lectotype a specimen from the syntype series.

Sampling positions of the Talisman and Travailleur cruises, the longitudes of which were initially measured with reference to the Paris meridian, have here been corrected to the Greenwich meridian by subtracting $2^{\circ} 20^{\prime} 14$ " from the longitude originally given (cf. Ryland 1969: 238).

\section{Description}

Colony presumably cellarinelliform (sensu Rosso 1992). Rods up to about $1 \mathrm{~cm}$ in length, cylindrical to oval in cross-section with constrictions at irregular intervals (Fig. 5A-E), which result from breakage and regeneration of the colony, or from a reduction in the number of distally budded zooids; ramifications or rhizoids were not observed; in fully developed colony parts, 3 zooids are simultaneously budded distally, and the rods are composed of an abfrontal side devoid of orifices on about one-fourth of the total perimeter (Fig. 5H), with the zooids opening at the latero-frontal sides (Fig. 5E) and being arranged in a plaited manner along the rod axis, i.e., zooids aligned in 3 alternating longitudinal series on each side of a median frontal (zigzag) line; all zooids inclined at about $45^{\circ}$ to rod axis, pointing towards the median frontal line (Fig. 5E, G, J). The zooids in these 3 series are polymorphic and decrease in size towards the median frontal line: the abfrontal side is exclusively composed of the extremely elongated proximal parts of the latero-abfrontally positioned series of zooecia of each side (Fig. $5 \mathrm{H}$ ), while the distal parts of these zooecia are bent around the rod axis and open along the lateral sides; zooecium shape very elongated hexagonal; the intermediate lateral series consist of distinctly shorter subrhomboidal zooecia (Fig. 5E, G, J), abutting distally against a zooecium of the median series from the other side of the median frontal line; zooecia of the median series even shorter and subhexagonal (Fig. 5E, G), opening at an angle of almost $90^{\circ}$ with respect to the latero-abfrontal zooecia. In between zooids at the median line, an orbicular opening is occasionally present that presumably marks the heterozooid from which a rhizoid is produced for colony support (Fig. 5J).

All zooecia separated by shallow grooves and indistinct meandering sutures owing to secondary calcification during later ontogeny; frontal shield slightly convex, distally forming a swollen, salient rim around distolateral orifice, surface distinctly nodular (Fig. 5G); few areolar pores of variable shape, usually situated in zooecial corners. Primary orifice somewhat immersed, situated at quite a distance to the distal zooecial margin (Fig. 5G), cleithridiate, slightly longer than wide, with a large suborbicular poster comprising about three quarters of a full circle and a very broadly U-shaped anter of about onethird of total orifice length and over half of orifice width, delimited by very short proximomedially directed condyles (Fig. 5F); orifice dimensions smaller in zooids of the median series than in those of the lateral and latero-abfrontal series. 
Ovicells were not observed.

Avicularia adventitious, small, transversely elliptical, usually two per zooecium (Fig. 5E, G, I-J): one in the distolateral corner that is closer to the median frontal line, and another one usually at the proximolateral zooecial margin; the latero-abfrontal zooids may have another avicularium at the very proximal zooecial margin; cystid slightly raised during early ontogeny, later levelled by secondary calcification. Rostrum much wider than long, semi-elliptical, with a slightly raised smooth distal rim, directed distolaterally (distal avicularia) or proximolaterally (proximal avicularia); crossbar complete, without columella; proximal uncalcified area transversely oval.
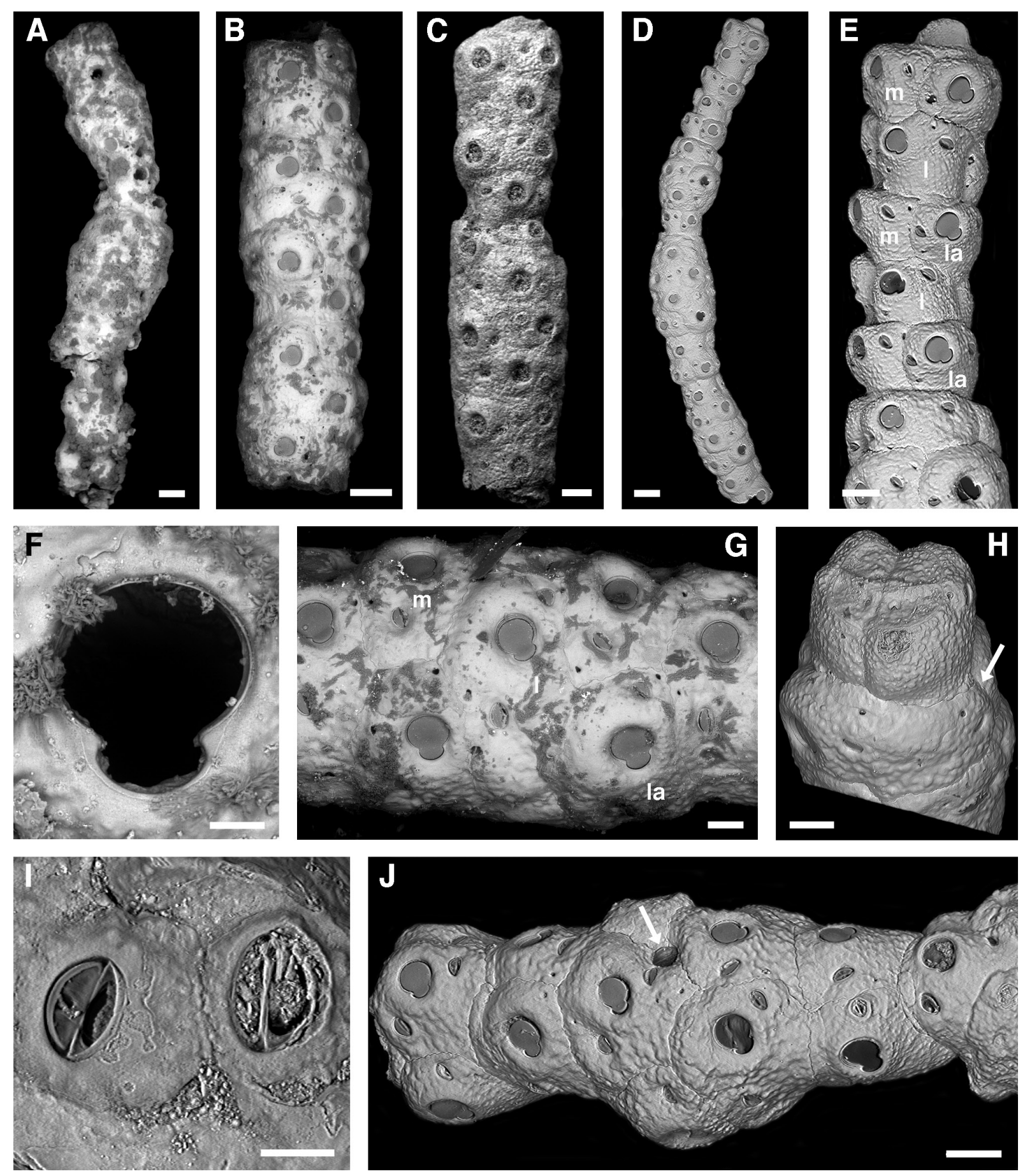
Table 5. Measurements (in $\mu \mathrm{m}$ ) of skeletal characters of Characodoma strangulatum (Calvet, 1906), taken from the syntype specimens MNHN 492, 493 and 2471 (see text for morphometric variability between specimens). Due to the convex colony surface, zooecial measurements of the extremely elongated latero-abfrontal zooids could not be taken. $\mathrm{SD}=$ standard deviation, $\mathrm{N}=$ number of measurements.

\begin{tabular}{|c|c|c|c|c|}
\hline & Mean & SD & Range & $\mathrm{N}$ \\
\hline Zooid length (median zooids) & 447 & 22 & $421-468$ & 5 \\
\hline Zooid width (median zooids) & 375 & 17 & $356-396$ & 5 \\
\hline Orifice length (median zooids) & 112 & 4 & $113-107$ & 5 \\
\hline Orifice width (median zooids) & 103 & 5 & $96-107$ & 5 \\
\hline Zooid length (lateral zooids) & 587 & 37 & $523-648$ & 8 \\
\hline Zooid width (lateral zooids) & 368 & 37 & $304-422$ & 8 \\
\hline Orifice length (lateral zooids) & 133 & 7 & $120-142$ & 14 \\
\hline Orifice width (lateral zooids) & 120 & 6 & $116-131$ & 14 \\
\hline Avicularium length & 45 & 4 & $36-54$ & 20 \\
\hline Avicularium width & 67 & 6 & $56-78$ & 20 \\
\hline Branch diameter & 776 & 62 & $678-860$ & 7 \\
\hline
\end{tabular}

Fig. 5 (page 18). Characodoma strangulatum (Calvet, 1906). A. Latero-abfrontal view of MNHN 492 (Canary Islands) from the syntype series, which is affected by Bynesian decay. B. Lateral view of MNHN 493 (NW Morocco) from the syntype series, a mature colony in which the zooecia are frontally thickened by secondary calcification; the abfrontal part (to the left) and the autozooecia from the opposite side cannot be seen in this view. C. Lateral view of MNHN 2471 (Mauritania) from the syntype series; the constriction in this colony was caused by zooid regeneration after damage and does not mark a conventional constriction in growth as seen in other specimens (photo: P. Kuklinski). D. A long rod with reversed polarity growth after damage at the colony centre, the lower half representing the primary colony from which the upper part was budded; in both parts growth constrictions occur that did not result from colony breakage (MNHN 19804, NW Morocco; photo: J. Souto). E. Close-up of the same specimen in lateral view showing ontogenetically young zooids that lack secondary calcification; the three differently positioned, polymorphic autozooids are indicated as "la" (elongated latero-abfrontal zooids), "l" (lateral zooids of intermediate size), and "m" (small median zooids) (MNHN 19804, NW Morocco; photo: J. Souto). F. Orifice (MNHN 492, Canary Islands); the calcium acetate crystals growing on the skeletal surface are the result of Bynesian decay owing to the specimen having been kept enclosed in a wooden slide in relatively humid conditions. G. Late ontogenetic polymorphic autoozooids (MNHN 493, NW Morocco); see E for abbreviations. H. The colony growth margin of another colony of sample MNHN 19804 (NW Morocco) with two zooids having been budded after a normal constriction in colony diameter; view of the abfrontal side of the rod with the extremely elongated latero-abfrontal zooid; the orifice is to the left whereas its proximal margin is at the very right (arrow) (photo: J. Souto). I. Close up of two avicularia (MNHN 19804, NW Morocco; photo: J. Souto). J. Yet another colony of sample MNHN 19804 (NW Morocco) showing the approximate median line at which zooids from both colony sides meet; note the orbicular opening of a kenozooid at the median line from which a rhizoid for colony attachment presumably originates (arrow) (photo: J. Souto). Scale bars: A-C, E, H, J = $200 \mu \mathrm{m} ; \mathrm{D}=400$ $\mu \mathrm{m} ; \mathrm{F}=30 \mu \mathrm{m} ; \mathrm{G}=100 \mu \mathrm{m} ; \mathrm{I}=50 \mu \mathrm{m}$. 
Early astogenetic stages absent in the examined material.

\section{Remarks}

In a revision of the Mediterranean species of the genus Characodoma Maplestone, 1900, Rosso (1999: 429) first assigned Myriozoum strangulatum to this genus when describing the closely related Pleistocene species Characodoma reclinatum Rosso, 1999. Although the characteristic ovicell could not be observed on any of the available material, the general zooidal and zoarial features of $C$. strangulatum correspond to those of Characodoma.

However, there are serious problems concerning the specific taxonomic identity of $C$. strangulatum that arise from the specimens of the syntype series. 1) The four syntypes are small colony fragments that are very poorly preserved. Specimen MNHN 947 is strongly affected by Bynesian decay and could not be studied in detail. MNHN 492 and 493 are also affected to varying degrees but some characters are still visible, while in MNHN 2471 all openings are filled with sediment. 2) Important species-specific characters are either entirely lacking in these specimens (e.g., ovicells) or are mostly obscured, such as the primary orifices, which are concealed by opercula in MNHN 493, or filled with sediment in MNHN 2471. Cleaning or bleaching of the specimens is presumably impossible without damaging or destroying the fragile colonies. Moreover, as they are glued onto slides, only a restricted number of measurements could be taken (cf. Table 5, and see below). 3) The specimens are from widely distant locations, with a distance of over $800 \mathrm{~km}$ between each of the three sampling regions (Mauritania, Canary Islands, Gulf of Cádiz). 4) Of the four specimens of the syntype series, two (MNHN 492 and 2471) resemble the original figure (Calvet 1907: pl. 26, fig. 11) owing to the presence of constrictions typical for the species. Neither of these two colonies can be unequivocally identified as the figured specimen, maybe because the colony surface depicted by Calvet cannot be seen in the mounted specimens, i.e., they were glued onto the slides with the wrong side facing upwards.

Thus, beyond the absence of ovicells and early astogenetic stages from all material assigned to $C$. strangulatum, the few small and poorly preserved specimens of the syntype series do not allow this species to be precisely defined. Moreover, the great geographic range of distribution and distance between sampling regions raises the question of whether all syntype specimens do indeed belong to the same species. For instance, the lateral zooids in specimen MNHN 493 have slightly smaller orifices (mean OL 124, OW 113, $\mathrm{N}=3$ ) than the remaining syntype specimens (mean OL 136, OW 122, $\mathrm{N}=$ 11), although the number of measurements is clearly too small to be statistically reliable. In contrast, the specimens reported from NW Morocco by Harmelin \& d'Hondt (1992; MNHN 19804), i.e., from the same region as MNHN 493 and MNHN 497, differ from the original suite of C. strangulatum in having distinctly larger orifices (mean OL $168 \mu \mathrm{m}$, OW $146 \mu \mathrm{m}, \mathrm{N}=10$ ), both measured in lateral and lateroabfrontal zooids (MNHN 19804, Fig. 5D, E, H, J).

Therefore, I consider the specimens of the syntype series as insufficiently preserved and lacking important diagnostic characters for the species to be precisely defined, and it cannot be ruled out that the syntype series comprises more than one distinct species. Hence, I will not designate a lectotype from the syntype series but suggest instead that a neotype should be chosen as soon as newly sampled material from either one of the three original sampling sites becomes available. In the present study, $C$. strangulatum is considered sensu lato, as is its geographic range and depth distribution.

Another incongruity concerns the avicularium: in the original figure of C. strangulatum (Calvet, 1907: pl. 26, fig. 12) the avicularia are depicted as having elongated and rather triangular rostra, instead of the extremely short and broad, semi-elliptical rostra reported in other specimens assigned to this species. Harmelin (1977) ascribed this difference to a possible intraspecific variability between populations inhabiting different environments. However, in none of the specimens of the "syntype series" are 
crossbars visible, either because they are broken and lost, or because the mandibles are still in place, concealing the skeletal structures underneath. Another possibility is that they are truly absent. In any case, it seems likely that, in the absence of any visible crossbars, Calvet decided that they should be, as in most other bryozoans, perpendicular to the longest avicularian dimension, and haphazardly added crossbars to the figure. That the avicularium is, indeed, broader than long in C. strangulatum is indicated by the slightly raised distal margin of the rostrum, while simple crossbars spanning the longest dimension are present in well-preserved specimens from central and northwestern Morocco that were assigned to C. strangulatum by Harmelin (1977) and Harmelin \& d'Hondt (1992), respectively (Fig. 5I).

Characodoma strangulatum has been recorded from depths between 600 and $3700 \mathrm{~m}$ and its geographic range is provisionally considered to stretch from southern Portugal along the Moroccan shelf, and via the Canary Islands to the Mauritanian slope, i.e., some $2000 \mathrm{~km}$ in N-S direction. The species occurs on muddy substrata and is, as other congeneric species (cf. Rosso 1999), likely to be anchored in the fine sediment by rhizoids. The rhizoids themselves were never observed, not even in well-preserved specimens from the Gulf of Cádiz recovered during the Balgim cruise (Harmelin \& d'Hondt 1992). This may not be surprising, as Hirose (2011) recently showed that, in certain species, rhizoids may be translucent and extremely delicate structures, and may thus be among the first tissue to decay after sampling. However, the orbicular kenozooidal openings situated along the frontal midline of the C. strangulatum colonies do suggest this mode of attachment (Fig. 5J). This means that the tentacles of the median zooids face towards the substratum when everted, which has already been inferred for other species of this genus (Rosso 1999). The relative proximity of the median zooids to the substratum may also explain the smaller orifice dimensions (i.e., smaller tentacles, if these traits are interrelated) in comparison with zooids from the lateral and latero-abfrontal series ( $c f$. Table 5). On the other hand, the small orifices may simply be correlated with the smaller zooid size of the median series owing to constructional constraints of the colony.

Undamaged zooecia with one or two intramural buds, recognisable by the presence of multiple orifice rims within the primary orifice ( $c f$. Berning 2008), were present in all of the studied colonies. Reparative growth within primary zooids may either be triggered by partial predation (Berning 2008) or, in (seasonally) oligotrophic conditions, by partial starvation (J.-G. Harmelin pers. comm. 2008). The typical constrictions within colonies of $C$. strangulatum (Fig. 5D), from which the specific epithet derives, may also be a response to seasonal reduction in food supply during which colony growth slows down or comes to a halt. The paucity of ovicells even in long rods, in concert with frequent signs of breakage and reparative growth at colony constrictions, may reflect another adaptation to unfavourable conditions. Instead of investing energy in embryos, propagation may more often proceed by fragmentation of the colonies at these constrictions (Fig. 5C, D). However, ovicells are commonly present in a very closely related, hitherto undescribed species from the Great Meteor Bank at similar depths (pers. observation). This seamount is situated in the central North Atlantic in certainly more oligotrophic conditions than the populations of $C$. strangulatum from the continental shelf and slope.

\section{Acknowledgements}

Mary Spencer Jones (NHMUK) is particularly thanked for her hospitality and help with the collection, literature, and for taking some of the images of H. mucronelliformis (as did Kevin Tilbrook, Museum of Tropical Queensland, Townsville). Jean-Loup d'Hondt and Pierre Lozouet (MNHN), Michèle Bruni (MOM), as well as Henry McGhie and Kate Sherburn (MM), kindly provided the type specimens of, and information on, their respective collections. To Piotr Kuklinski (NHMUK) and Javier Souto (Universidade de Santiago de Compostela) I am grateful for taking some of the photos of C. strangulatum. Furthermore, I thank J. Souto, Oscar Reverter-Gil (Santiago), Andrey Ostrovsky (Universities of St. Petersburg and Vienna), Dennis Gordon (NIWA Wellington), Jean-Georges Harmelin (Centre d'Océanologie de Marseille), Steven Tracey (NHMUK), and an anoynmous reviewer for fruitful discussions and exchange 
of vital information. This research received support from the SYNTHESYS Project (http://www. synthesys.info/), which is financed by the European Community Research Infrastructure Action under the FP7 "Capacities" Program, and which allowed me to study some of the type material at the MNHN (FR-TAF-1902).

\section{References}

Arístegui J. 1985. The genus Adeonellopsis MacGillivray (Bryozoa: Cheilostomata) in the Canary Islands: A. distoma (Busk) and A. multiporosa sp. nov. Journal of Natural History 19 (3): 425-430. http://dx.doi.org/10.1080/00222938500770311

Berning B. 2006. The cheilostome bryozoan fauna from the Late Miocene of Niebla (Guadalquivir Basin, SW Spain): environmental and biogeographic implications. Mitteilungen aus dem GeologischPaläontologischen Institut der Universität Hamburg 90: 7-156.

Berning B. 2007. The Mediterranean bryozoan Myriapora truncata (Pallas, 1766): a potential indicator of (palaeo-) environmental conditions. Lethaia 40: 221-232. http://dx.doi.org/10.1111/j.15023931.2007.00019.x

Berning B. 2008. Evidence for sublethal predation and regeneration among living and fossil ascophoran bryozoans. In: Hageman S.J., Key M.M. \& Winston J.E. (eds), Bryozoan Studies 2007. Virginia Museum of Natural History Special Publication 15: 1-7.

Berning B. 2012. Taxonomic notes on some Cheilostomata (Bryozoa) from Madeira. Zootaxa 3236: $36-54$

Berning B. \& Kuklinski P. 2008. North-east Atlantic and Mediterranean species of the genus Buffonellaria (Bryozoa, Cheilostomata): implications for biodiversity and biogeography. Zoological Journal of the Linnean Society 152: 537-566. http://dx.doi.org/10.1111/j.1096-3642.2007.00379.x

Berning B., Tilbrook K.J. \& Rosso A. 2008. Revision of the north-eastern Atlantic and Mediterranean species of the genera Herentia and Therenia (Bryozoa: Cheilostomata). Journal of Natural History 42: 1509-1547. http://dx.doi.org/10.1080/00222930802109140

Brown D.A. 1949. On the polyzoan genus Hippomenella Canu \& Bassler and its genotype Lepralia mucronelliformis Waters. Journal of the Linnean Society, Zoology 41: 513-520. http://dx.doi. org/10.1111/j.1096-3642.1940.tb02419.x

Brown D.A. 1952. The Tertiary Cheilostomatous Polyzoa of New Zealand. Trustees of the British Museum (Natural History), London.

Brown D.A. 1958. Fossil cheilostomatous Polyzoa from south-west Victoria. Memoirs of the Geological Survey of Victoria 20: 1-90.

Calvet L. 1906. Note préliminaire sur les bryozoaires recueillis par les expéditions du Travailleur (18811882) et du Talisman (1883). Bulletin du Muséum National d'Histoire Naturelle, Paris 12: 154-166.

Calvet L. 1907. Bryozoaires. Expéditions scientifiques du "Travailleur" et du "Talisman" pendant les années 1880-1883 8: 355-495.

Calvet L. 1931. Bryozoaires provenant des campagnes scientifiques du Prince Albert $1^{\text {er }}$ de Monaco. Résultats des Campagnes Scientifiques du Prince Albert $1^{\text {er }}$ de Monaco 83: 1-152.

Canu F. \& Bassler R.S. 1917. A synopsis of American early Tertiary cheilostome Bryozoa. United States National Museum Bulletin 96: 7-87.

Canu F. \& Bassler R.S. 1925. Les Bryozoaires du Maroc et de Mauritanie, $1^{\text {er }}$ Mémoire. Mémoires de la Société des Sciences Naturelles du Maroc 10: 1-79. 
El Hajjaji K. 1992. Les Bryozoaires du Miocène supérieur du Maroc nord-oriental. Documents des Laboratoires de Géologie Lyon 123: 1-355.

Ferretti C., Magnino G. \& Balduzzi A. 2007. Morphology of the larva and ancestrula of Myriapora truncata (Bryozoa, Cheilostomatida). Italian Journal of Zoology 74: 341-350. http://dx.doi. org/10.1080/11250000701629572

Gabb W.M. \& Horn G.H. 1862. Monograph of the fossil Polyzoa of the Secondary and Tertiary formations of North America. Journal of the Academy of Natural Sciences of Philadelphia 5: 111-179.

Gordon D.P. 1984. The marine fauna of New Zealand: Bryozoa: Gymnolaemata from the Kermadec Ridge. New Zealand Oceanographic Institute Memoirs 91: 1-198.

Gordon D.P. 1989. The marine fauna of New Zealand: Bryozoa: Gymnolaemata (Cheilostomatida Ascophorina) from the western South Island continental shelf and slope. New Zealand Oceanographic Institute Memoir 97: 1-158.

Gordon D.P. \& d'Hondt J.-L. 1997. Bryozoa: Lepraliomorpha and other Ascophorina, mainly from New Caledonian waters. Mémoires du Muséum National d'Histoire Naturelle 176: 9-124.

Gordon D.P., Stuart I.G. \& Collen J.D. 1994. Bryozoan fauna of the Kaipuke Siltstone, northwest Nelson: a Miocene homologue of the modern Tasman Bay coralline bryozoan grounds. New Zealand Journal of Geology and Geophysics 37: 239-247.

Harmelin J.-G. 1969. Bryozoaires récoltés au cours de la campagne du Jean Charcot en Méditerranée orientale (Août-Septembre 1967) - I. Dragages. Bulletin du Muséum National d'Histoire Naturelle, $2 e$ série 40: 1179-1208.

Harmelin J.-G. 1977. Bryozoaires du Banc de la Conception (nord des Canaries). Campagne Cineca I du "Jean Charcot". Bulletin du Muséum National d'Histoire Naturelle, 3e série 492: 1057-1076.

Harmelin J.-G. 1978. Sur quelques Cribrimorphes (Bryozoa, Cheilostomata) de l'Atlantique Oriental. Téthys 8: 173-192.

Harmelin J.-G. \& Arístegui J. 1988. New Cribrilinidae (Bryozoa, Cheilostomata) from the upper bathyal of the Atlanto-Mediterranean region. Journal of Natural History 22 (2): 507-535. http://dx.doi. org/10.1080/00222938800770351

Harmelin J.-G. \& d'Hondt J.-L. 1992. Bryozoaires des parages de Gibraltar (campagne océanographique BALGIM, 1984). 1 - Chéilostomes. Bulletin du Muséum National d'Histoire Naturelle, Paris, 4 é série 14: 23-67.

Hastings A.B. 1966. Observations on the type-material of some genera and species of Polyzoa. Bulletin of the British Museum (Natural History), Zoology 14: 55-78.

Hayward P.J. 1974. Studies on the cheilostome bryozoan fauna of the Aegean island of Chios. Journal of Natural History 8 (4): 369-402. http://dx.doi.org/10.1080/00222937400770321

Hayward P.J. 1978. Bryozoa from the west European continental slope. Journal of Zoology 184 (2): 207224. http://dx.doi.org/10.1111/j.1469-7998.1978.tb03276.x

Hayward P.J. \& Ryland J.S. 1978. Bryozoa from the Bay of Biscay and Western Approaches. Journal of the Marine Biological Association of the United Kingdom 58: 143-159.

Hayward P.J. \& Winston J.E. 2011. Bryozoa collected by the United States Antarctic Research Program: new taxa and new records. Journal of Natural History 45: 2259-2338. http://dx.doi.org/10.1080/00222 933.2011.574922

Hirose M. 2011. Orientation and righting behavior of the sand-dwelling bryozoan Conescharellina catella. Invertebrate Biology 130 (3): 282-290. http://dx.doi.org/10.1111/j.1744-7410.2011.00237.x 
d'Hondt J.-L. 1973. Bryozoaires de la campagne de la „Thalassa“ (3-12 août 1967). Bulletin du Muséum National d'Histoire Naturelle, $3^{e}$ série 120: 365-386.

d'Hondt J.-L. 1975. Bryozoaires Cténostomes et Cheilostomes (Cribrimorphes et Escharellidae exceptés) provenant des dragages de la campagne océanographique Biaçores du "Jean Charcot". Bulletin du Muséum National d'Histoire Naturelle, Paris, $3^{e}$ série 299: 553-600.

ICZN. 1999. International Code of Zoological Nomenclature. International Trust for Zoological Nomenclature, London.

Jullien J. 1883. Dragages du Travailleur - Bryozoaires. Espèces draguées dans l'Océan Atlantique en 1881. Bulletin de la Société Zoologique de France 7: 497-529.

Jullien J. 1888. Bryozoaires. Mission Scientifique du Cap Horn 1882-1883 6: 1-92.

Jullien J. \& Calvet L. 1903. Bryozoaires provenant des campagnes de l'Hirondelle (1886-1888). Résultats des Campagnes Scientifiques du Prince de Monaco 23: 1-188.

López de la Cuadra C.M. \& García-Gómez J.C. 1993. Little-known Atlantic cheilostome bryozoans at the entrance to the Mediterranean. Journal of Natural History 27 (2): 457-469. http://dx.doi. org/10.1080/00222939300770221

López de la Cuadra C.M. \& García-Gómez J.C. 1996. The species of Cellaria (Bryozoa: Cheilostomatida) with large avicularia from West Africa. Journal of Natural History 30 (1): 153-161. http://dx.doi. org/10.1080/00222939600770101

López-Fé C.M. 2006. Some bathyal cheilostome Bryozoa (Bryozoa, Cheilostomata) from the Canary Islands (Spain, Eastern Atlantic), with descriptions of three new species, a new genus, and a new family. Journal of Natural History 40: 1801-1812. http://dx.doi.org/10.1080/00222930601043763

Norman A.M. 1909. The Polyzoa of Madeira and neighbouring islands. Journal of the Linnean Society, Zoology 30: 275-314. http://dx.doi.org/10.1111/j.1096-3642.1909.tb02407.x

Piepenburg D. \& Müller B. 2004. Distribution of epibenthic communities on the Great Meteor Seamount (north-east Atlantic) mirrors pelagic processes. Archive of Fishery and Marine Research 51: 55-70.

Pouyet S. \& Moissette P. 1992. Bryozoaires du Pliocène d'Altavilla (Sicile-Italie): révision de la collection Cipolla, nouvelles données, paléoécologie. Palaeontographica, Abt. A 223: 19-101.

Reverter-Gil O. \& Fernández-Pulpeiro E. 1996. Cribrilinidae (Bryozoa: Cheilostomatida) from the Ría de Ferrol (NW Spain). Journal of Natural History 30: 1247-1260.

Reverter-Gil O. \& Fernández-Pulpeiro E. 1999a. Some little-known species of Bryozoa described by J. Jullien. Journal of Natural History 33 (9): 1403-1418. http://dx.doi.org/10.1080/002229399299941

Reverter-Gil O. \& Fernández-Pulpeiro E. 1999b. Some records of bryozoans from NW Spain. Cahiers de Biologie Marine 40: 35-45.

Reverter-Gil O., Souto J. \& Fernández-Pulpeiro E. 2009. Three new species of Iberian cheilostomate Bryozoa. Journal of the Marine Biological Association of the United Kingdom 89: 1499-1506. http:// dx.doi.org/doi:10.1017/S0025315409000496

Reverter-Gil O., Souto J. \& Fernández-Pulpeiro E. 2012. New and little known species of Bryozoa from Iberian Atlantic waters. Zoosystema 34: 157-170. http://dx.doi.org/10.5252/z2012n1a7

Rodolfo-Metalpa R., Lombardi C., Cocito S., Hall-Spencer J.M. \& Gambi M.C. 2010. Effects of ocean acidification and high temperatures on the bryozoan Myriapora truncata at natural $\mathrm{CO}_{2}$ vents. Marine Ecology 31: 447-456. http://dx.doi.org/10.1111/j.1439-0485.2009.00354.x 
Rosso A. 1992. Bryozoa from Terra Nova Bay (Ross Sea, Antarctica). Oceanografia in Antartide, pp. 359-369, Concepción.

Rosso A. 1999. Recent and fossil species of Characodoma Maplestone, 1900 (Bryozoa) from the Mediterranean with description of two new species. Journal of Natural History 33 (3): 415-437. http:// dx.doi.org/10.1080/002229399300326

Ryland J.S. 1969. A nomenclatural index to "A History of the British Marine Polyzoa" by T. Hincks (1880). Bulletin of the British Museum (Natural History), Zoology 17: 205-260.

Sefian N.L., Pouyet S. \& El Hajjaji K. 1999. Bryozoaires du Miocène supérieur de Charf el Akab (NW Maroc). Revue de Paléobiologie 18: 221-252.

Souto J., Reverter-Gil O. \& Fernández-Pulpeiro E. 2010. Gymnolaemate bryozoans from the Algarve (southern Portugal): new species and biogeographical considerations. Journal of the Marine Biological Association of the United Kingdom 90: 1417-1439. http://dx.doi.org/10.1017/S0025315409991640

Souto J., Reverter-Gil O. \& Fernández-Pulpeiro E. 2011. Redescription of some bryozoan species originally described by J. Jullien from Iberian waters. Zootaxa 2827: 31-53.

Tilbrook K.J. 2006. Cheilostomatous Bryozoa from the Solomon Islands. Santa Barbara Museum of Natural History Monographs 4: 1-385.

Tricart S. \& d'Hondt J.-L. 2009. Catalogue des spécimens-types de Bryozoaires, Brachiopodes, Ptérobranches et Entéropneustes du Département "Milieux et Peuplements Aquatiques" (Museum National d'Histoire Naturelle, Paris). Mémoires de la Société Linnéenne de Bordeaux 11: 1-144.

Vieira L.M., Gordon D.P., Souza F.B.C. \& Haddad M.A. 2010. New and little-known cheilostomatous Bryozoa from the south and southeastern Brazilian continental shelf and slope. Zootaxa 2722: 1-53.

Viskova L.A. 1986. The morphology and colonial integration of the genus Myriapora (Cheilostomata). Paleontologicheskii Zhurnal 4: 56-64.

Waters A.W. 1899. Bryozoa from Madeira. Journal of the Royal Microscopical Society 1899: 6-16.

Zabala M. 1986. Fauna dels Briozous dels Paisos Catalans. Institut d'Estudis Catalans, Arxius de la Secció de Ciènces, Barcelona 84: 1-836.

Zabala M. \& Maluquer P. 1988. Illustrated Keys for the Classification of Mediterranean Bryozoa. Treballs del Museu de Zoologia, Barcelona 4: 1-294.

Zágorsek K. 2010. Bryozoa from the Langhian (Miocene) of the Czech Republic. Part II: Systematic description of the suborder Ascophora Levinsen, 1909 and paleoecological reconstruction of the studied paleoenvironment. Acta Musei Nationalis Pragae, Series B - Historia Naturalis 66: 139-255.

Manuscript received: 9 February 2013

Manuscript accepted: 10 April 2013

Published on: 21 May 2013

Topic editor: Rudy Jocqué

Desk editor: Kristiaan Hoedemakers

Printed versions of all papers are also deposited in the libraries of the institutes that are members of the EJT consortium: Muséum National d'Histoire Naturelle, Paris, France; National Botanic Garden of Belgium, Meise, Belgium; Royal Museum for Central Africa, Tervuren, Belgium; Natural History Museum, London, United Kingdom; Royal Belgian Institute of Natural Sciences, Brussels, Belgium; Natural History Museum of Denmark, Copenhagen, Denmark. 